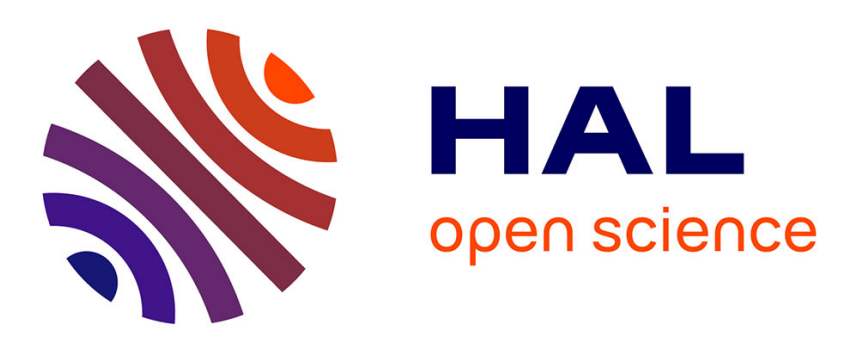

\title{
Evidence of active or passive downwind dispersal in mark-release-recapture of moths
}

Sylvain Guichard, Darren. J. D. J. Kriticos, Agathe Leriche, S.P. Worner, J. Keane, David Maxwell Suckling

\section{> To cite this version:}

Sylvain Guichard, Darren. J. D. J. Kriticos, Agathe Leriche, S.P. Worner, J. Keane, et al.. Evidence of active or passive downwind dispersal in mark-release-recapture of moths. Entomologia Experimentalis et Applicata, 2010, 134 (2), pp.160 - 169. 10.1111/j.1570-7458.2009.00950.x . hal-01787710

\section{HAL Id: hal-01787710 \\ https://hal-amu.archives-ouvertes.fr/hal-01787710}

Submitted on 7 May 2018

HAL is a multi-disciplinary open access archive for the deposit and dissemination of scientific research documents, whether they are published or not. The documents may come from teaching and research institutions in France or abroad, or from public or private research centers.
L'archive ouverte pluridisciplinaire HAL, est destinée au dépôt et à la diffusion de documents scientifiques de niveau recherche, publiés ou non, émanant des établissements d'enseignement et de recherche français ou étrangers, des laboratoires publics ou privés. 


\title{
Evidence of active or passive downwind dispersal in mark-release-recapture of moths
}

\author{
S. Guichard ${ }^{1,2 *}$, D. J. Kriticos ${ }^{2}$, A. Leriche ${ }^{2 \S}$, S. P. Worner ${ }^{3}$, J. M. Kean ${ }^{4}$ \& D. M. Suckling ${ }^{5}$ \\ ${ }^{1}$ Scion New Forests \& Forestry Science, PO Box 3020, Rotorua, New Zealand, ${ }^{2}$ CSIRO Entomology, GPO Box 1700, Canber- \\ ra, ACT, Australia, ${ }^{3}$ Lincoln University, Bio-Protection and Ecology Division, Canterbury, New Zealand, ${ }^{4}$ AgResearch, \\ Private Bag 4749, Christchurch, New Zealand, and ${ }^{5}$ The New Zealand Institute for Plant and Food Research, PO Box 4704, \\ Christchurch, New Zealand
}

Key words: anemotaxis, appetitive behaviour, biosecurity, Lepidoptera, Lymantriidae, pheromone, Teia anartoides

\begin{abstract}
Modelling moth dispersal in relation to wind direction and strength could greatly enhance the role of pheromone traps in biosecurity and pest management applications. Anemotaxis theory, which describes moth behaviour in the presence of a pheromone plume and is used as a framework for such models. Currently, however, that theory includes only three components: upwind, zigzagging, and sideways casting behaviour. We test anemotaxis theory by analysing the data from a series of markrelease-recapture experiments where the wind direction was known and the insects were trapped using an irregular grid of pheromone traps. The trapping results provide evidence of a downwind component to the flight patterns of the released insects. This active or passive downwind dispersal is likely to be an appetitive behaviour, occurring prior to the elicitation of pheromone-oriented flight patterns (pheromone anemotaxis). Given the potential for significant displacement during downwind dispersal, this component will have impact on final trap captures and should be considered when constructing moth dispersal models.
\end{abstract}

\section{Introduction}

Pheromone baited traps are widely used for biosecurity surveillance to detect new incursions of unwanted organisms, and to delimit their ranges (Augustin et al., 2004; Suckling et al., 2005a,b; Bogich et al., 2008; Liebhold \& Tobin, 2008). They have been used for several decades in pest management for monitoring to alert land managers to the presence of a pest in time and space, providing insight into phenology as well as geographic distribution (Suckling et al., 2005b). Pheromone traps have also been used to delimit populations for pest risk modelling (Kriticos et al., 2007). When deployment of a surveillance grid of traps is warranted to monitor for biological invasions, the detection of an unwanted organism typically triggers a delimitation survey to identify the proximal source of the

*Correspondence: Sylvain Guichard, CSIRO Entomology, GPO Box 1700, Canberra, ACT 2601, Australia. E-mail: Sylvain.Guichard@ hotmail.com

${ }^{\$}$ Present address: Université Aix Marseille 3, IMEP, CNRS, UMR 6116, BP80, F-13545 Aix en Provence, France incursion, the extent of the incursion population, the feasibility of eradication, and possibly the pathway by which the organism entered the jurisdiction (Canadian Food Inspection Agency, 2007). As such surveys are resource intensive, new technologies are needed to target them better. If the flight path or even direction of an insect from the proximal source of the invasive population to the pheromone trap could be inferred with some reliability, then on-ground delimitation surveys can be prioritised to those areas most likely to include the source location from which the trapped individual originated, and the most likely location of the remainder of its cohort.

Modelling the flight paths of individual insects from point of origin to their trapping point requires knowledge of their anemotaxis (any purposeful behaviour that is oriented in relation to the wind direction). Odour-mediated anemotaxis is the mechanism that insects employ to locate an odour source such as a female emitting a pheromone (Kennedy \& Marsh, 1974; David et al., 1983; Kennedy, 1983; Vickers, 2000; Cardé \& Willis, 2008). Within a pheromone plume, insects experience the fine structure of pheromone intermittency with pheromone filaments 
separated by gaps of clean air (Murlis \& Jones, 1981; Baker \& Haynes, 1989; Mafra-Neto \& Cardé, 1994; Riffell et al., 2008). The response of the insect as it alternately senses the pheromone or clean air at millisecond frequencies is the so-called 'pheromone anemotaxis behaviour', which results in a net upwind displacement that ultimately guides flying insects to an odour source. When a filament of pheromone is detected, the insect flies upwind, but as the pheromone filament is lost, the insect begins to fly in a zigzag pattern to locate another pheromone filament from the same plume (Kennedy et al., 1980; Vickers \& Baker, 1996; Zanen \& Cardé, 1999). When the insect exits from the pheromone plume, large crosswind movements are observed (Baker \& Haynes, 1987; Kuenen \& Cardé, 1994; Mafra-Neto \& Cardé, 1998). Presumably this behaviour is triggered or promoted by a long time period without encountering a pheromone filament. This behaviour was originally demonstrated with moths but it has also been observed for various other insect taxa such as some beetles (Fadamiro et al., 1998; Kuenen \& Rowe, 2006; Williams et al., 2007).

Pheromone anemotaxis theory focuses on insect behaviour within the pheromone plume, and is mainly based on wind tunnel studies. Behaviour at a broader scale than within the odour plume is not so well understood. Several authors have suggested that the optimal strategy to locate a pheromone source depends, unsurprisingly, on the wind conditions. Dusenbery (1989) suggests that in a steady wind, the most effective flight course is oriented around $45^{\circ}$ from downwind, whereas with a wind shifting up to $30^{\circ}$ from the mean direction, the most effective strategy is crosswind flight (Sabelis \& Schippers, 1984). For winds that shift over a wider range, Sabelis \& Schippers (1984) suggested a search strategy parallel to the wind, but Dusenbery (1990) used a more complete analysis to conclude that the optimal strategy is upwind flight rather than downwind. Reynolds et al. (2007) confirmed these studies in an analysis accounting for a more realistic plume shape: downwind flights were preferable than crosswind when the width of the plume was greater than its length, when for example the plume was meandering due to a shifting wind. Reynolds et al. (2007) demonstrated that a biased Lévy flight searching strategy, optimal with a scaling exponent between 1 and 2, was consistent with their observations.

In contrast to the number of studies of insect behaviour within a pheromone plume (Murlis et al., 1992; Cardé \& Willis, 2008), few experimental studies have investigated 'appetitive' insect behaviour, defined by Elkinton \& Cardé (1983) as the behaviour before any contact with the pheromone. Those few studies include field experiments by Elkinton \& Cardé (1983), who reported a random behaviour for the appetitive flight of gypsy moth, and Riley et al. (1998), who reported occasional appetitive downwind flights in Agrotis segetum (Denis \& Schiffermüller) moths. Monitoring flight patterns with harmonic radar, Reynolds et al. (2007) demonstrated a trend of crosswind or downwind movements at the departure location before anemotaxis behaviour commenced following an initial encounter with the pheromone.

We believe that describing insect behaviour before any contact with a pheromone, as well as the behaviour within the pheromone plume is necessary to identify the source location of insects caught in pheromone traps. In this study, we re-analysed data from a study by Suckling et al. (2005a) on mark-release-recapture of sterile painted apple moths, Teia anartoides (Walker) (Lepidoptera: Lymantriidae), together with a generalised wind field. Moth flight was related to wind speed and direction to determine elements of dispersal in relation to the wind.

Teia anartoides is an Australian native lymantriid (Common, 1990) that became established in Auckland, New Zealand, in the 1990s (Hoare, 2001). Larvae are polyphagous and can affect the growth of plants of importance to horticulture and forestry such as pine trees, but can also feed on New Zealand indigenous trees. The estimated cost of T. anartoides establishment in New Zealand ranged from NZD 58 to 356 million over 20 years as a result of its wide host range (Self, 2003). An eradication programme against $T$. anartoides was undertaken from 1999 to 2006, and it was declared successfully eradicated in 2006 on the basis of a trapping model using sterile males (Kean \& Suckling, 2005; Suckling et al., 2007). The eradication including health monitoring, communication, and the operation was budgeted at an estimated NZD 100 million (Turner et al., 2004), which was later revised to closer to NZD 62.4 million actually spent (Anderton, 2006). In this study, the analysis of moth dispersal in relation to the wind provided elements of discussion on moth strategy to find a mate and therefore on the understanding and interpretation of pheromone trap catches.

\section{Materials and methods}

\section{Release-recapture data}

Experiments were conducted in Auckland between February and May 2003 with an average of 1452 traps to cover the study area (Suckling et al., 2005a). Delta traps baited with virgin female moths were deployed, as the main component of the synthetic pheromone is instable (El-Sayed et al., 2005). Adult moths were marked with fluorescent powders coloured differently for each of three release locations [Hobsonville $\left(36^{\circ} 47^{\prime} 35^{\prime \prime} \mathrm{S}, 174^{\circ} 39^{\prime} 12^{\prime \prime} \mathrm{E}\right)$, Waikumete Cemetery $\left(36^{\circ} 54^{\prime} 04^{\prime \prime} \mathrm{S}, 174^{\circ} 38^{\prime} 42^{\prime \prime} \mathrm{E}\right)$, and Ranui 
( $\left.36^{\circ} 51^{\prime} 59^{\prime \prime} \mathrm{S}, 174^{\circ} 35^{\prime} 52^{\prime \prime} \mathrm{E}\right)$; see Figure 1] (Suckling et al., 2005a). The habitat of release and recapture sites varied from urban and suburban type around Auckland to forest, mainly on the Western side of the area.

The data considered in this study were limited to the period from 19 February 2003 to 31 March 2003 when more than $1 \%$ of insects were recaptured and when insects were released weekly. Low recapture rates in subsequent release periods were likely due to suboptimal conditions immediately following release, including temperatures below the threshold for flight (Suckling et al., 2005a). Some releases in subsequent periods were also done twice each week (Kean et al. 2007). Painted apple moths survived in the field for approximately 4 days (Suckling et al., 2005a), and so recaptures cannot be clearly distinguished between two releases separated by $<5$ days. During the 6 -week duration of the markrelease-recapture experiment, a total of 16355 moths were released at all locations and 1481 or $9 \%$ of the total were recaptured in female-baited traps (Table 1). The

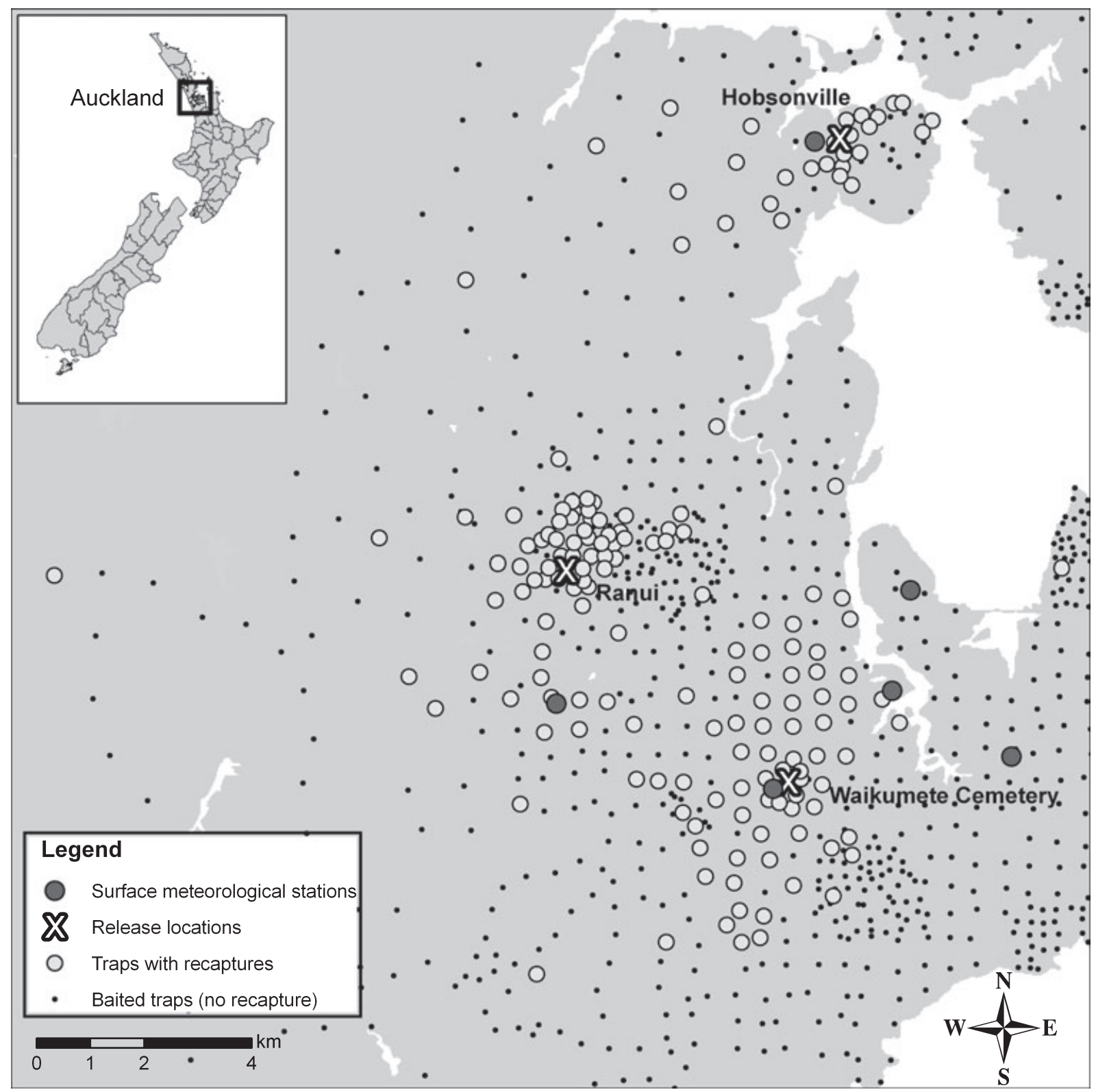

Figure 1 Distribution of recaptures around the three release locations in Auckland, New Zealand. 
Table 1 Number of painted apple moths released and recaptured at the various locations in Auckland, New Zealand, and release date considered in this study (from Suckling et al., 2005a)

\begin{tabular}{|c|c|c|c|c|c|c|}
\hline \multirow[b]{2}{*}{ Location period } & \multicolumn{2}{|c|}{ Hobsonville } & \multicolumn{2}{|c|}{ Waikumete Cemetery } & \multicolumn{2}{|l|}{ Ranui } \\
\hline & Release & Recapture & Release & Recapture & Release & Recapture \\
\hline 19-25 February & 413 & 63 & 434 & 32 & 0 & 0 \\
\hline 28 February-4 March & 1128 & 103 & 1436 & 324 & 330 & 39 \\
\hline 6-10 March & 814 & 81 & 795 & 131 & 892 & 175 \\
\hline 13-20 March & 1444 & 34 & 1292 & 101 & 1440 & 111 \\
\hline 21-25 March & 1191 & 25 & 1129 & 59 & 1036 & 13 \\
\hline 28-31 March & 866 & 19 & 850 & 154 & 865 & 17 \\
\hline
\end{tabular}

average number of insects released was 962 males (range: 330-1 444) per release location and week (Table 1). Insects were released around 10:00 hours, which corresponded to the beginning of the period of flight activity. Prior to each release, traps were reset with new sticky bases and baited with a fresh virgin female, and each trap was checked at most once per week. Therefore, a recapture recorded on a particular day had occurred between that day and the more recent of the release days or the last day the trap was checked. Parameters affecting female moth performance have been examined elsewhere (Suckling et al., 2006).

\section{Weather data collection and meteorological modelling}

Six meteorological stations (Figure 1) recorded wind direction and speed at 1- or 10-min intervals using a Vector A101M Pulse ${ }^{\circledR}$ output anemometer (Vector Instruments, Rhyl, UK). One-minute wind direction and speed were averaged over $10 \mathrm{~min}$ after transformation of wind polar coordinates into rectangular coordinates (Batschelet, 1981). These meteorological stations also provided relative humidity and temperature measurements for every minute and these data were also averaged over $10 \mathrm{~min}$.

Atmospheric pressure, cloud cover, and cloud height were extracted from the New Zealand National Climate Database for three nearby meteorological stations $\left(36^{\circ} 59^{\prime} 28^{\prime \prime} \mathrm{S}, 174^{\circ} 52^{\prime} 12^{\prime \prime} \mathrm{E} ; 37^{\circ} 00^{\prime} 18^{\prime \prime} \mathrm{S}, 174^{\circ} 47^{\prime} 21^{\prime \prime} \mathrm{E}\right.$; and $36^{\circ} 47^{\prime} 34^{\prime \prime}$ S, $\left.174^{\circ} 37^{\prime} 26^{\prime \prime} \mathrm{E}\right)$. The hourly values for these variables were linearly interpolated to $10 \mathrm{~min}$ values. Twice daily, vertical profiles of pressure, elevation, temperature, wind direction, and wind speed for each sounding level were extracted from the New Zealand Climate Database for the nearest upper air meteorological station $\left(36^{\circ} 47^{\prime} 34^{\prime \prime} \mathrm{S}, 174^{\circ} 37^{\prime} 26^{\prime \prime} \mathrm{E}\right)$. The wind direction and wind speed data for the duration of each release-recapture period were interpolated onto a $200 \times 200 \mathrm{~m}$ series of 10 -min grids covering the study area using CALMET modelling software (Scire et al., 1998; Wang et al., 2008).

\section{Estimation of mean wind direction}

For each release location the mean wind direction was calculated from wind rectangular coordinates at 10 -min intervals from 10:00 to 15:00 hours for the day of release, corresponding to the main flight period of painted apple moth (Table 2). A transformation was required to convert wind polar coordinates (given by the angle and velocity of the wind) into rectangular coordinates (given by the coordinates of the wind vector) (Batschelet, 1981).

\section{Wind direction and recapture pattern}

The influence of wind characteristics during the day of release on the subsequent recapture patterns of the released moths was investigated by comparing recapture distances, after segregating the data by wind direction. A line orthog-

Table 2 Average wind direction and velocity (from 10-min intervals) for the main flying period of painted apple moth (10:0015:00 hours) at the three release locations in Auckland, New Zealand

\begin{tabular}{|c|c|c|c|c|c|c|}
\hline \multirow[b]{2}{*}{ Location date } & \multicolumn{2}{|l|}{ Hobsonville } & \multicolumn{2}{|c|}{ Waikumete Cemetery } & \multicolumn{2}{|l|}{ Ranui } \\
\hline & Direction $\left({ }^{\circ} \mathrm{N}\right)$ & Velocity $\left(\mathrm{m} \mathrm{s}^{-1}\right)$ & Direction $\left({ }^{\circ} \mathrm{N}\right)$ & Velocity $\left(\mathrm{m} \mathrm{s}^{-1}\right)$ & Direction $\left({ }^{\circ} \mathrm{N}\right)$ & Velocity $\left(\mathrm{m} \mathrm{s}^{-1}\right)$ \\
\hline 19 February & 135 & 1.24 & 127 & 1.79 & - & - \\
\hline 28 February & 235 & 3.47 & 235 & 5.06 & 265 & 4.28 \\
\hline 6 March & 359 & 2.44 & 348 & 2.67 & 345 & 2.22 \\
\hline 13 March & 28 & 5.16 & 64 & 6.73 & 38 & 5.29 \\
\hline 21 March & 252 & 2.64 & 277 & 3.88 & 268 & 3.51 \\
\hline $28 \mathrm{March}$ & 247 & 4.28 & 309 & 6.89 & 266 & 5.62 \\
\hline
\end{tabular}


onal to the mean wind direction across the release location was used to split the data between upwind and downwind recaptures. Each trap distance was expressed as the shortest distance to the trap from this line. This transformation allowed measurement of downwind or upwind displacement ignoring any crosswind displacement. The same method was applied to split the data left and right relative to the wind, thereby removing the downwind and upwind components to highlight net crosswind displacement. After this reclassification into either net left-right or upwind-downwind flight, the frequency distributions of recapture net displacement were compared using Pearson's $\chi^{2}$-test (S-plus 6.1; TIBCO Software, Palo Alto, CA, USA) to test for any dominant dispersal direction.

To measure directedness in the recapture patterns, in other words, the main direction of the distribution of recaptures, we also investigated the relative position of the centre of mass of the recaptures. The direction of each recapture was calculated relative to the mean wind on the day of release and the data were expressed as: (1) distance from the release location, and (2) deviation from the downwind direction. The latter was calculated as the difference between recapture and wind directions. The distribution of resulting points represented the recapture pattern with respect to the mean wind on the day of release, and allowed replicates from different release dates and locations to be compared. We then calculated the location of the centre of mass of this distribution of points, considering all recaptures as independent events. For $\mathrm{n}$ sample points defined by their coordinates $(\mathrm{x}, \mathrm{y})$, the centre of mass $(\bar{x}, \bar{y})$ was estimated by the average vector (1) for the sample.

$$
\bar{x}=\frac{1}{n} \sum_{i}^{n} x_{i} \text { and } \bar{y}=\frac{1}{n} \sum_{i}^{n} y_{i} .
$$

To test whether the recaptures were oriented about a mean direction, we determined the confidence ellipse for the centre of mass and applied Hotelling's test of significance (Batschelet, 1981). Based on a distribution of sample points, the confidence ellipse covers the region where the centre of mass for the population is located (Batschelet, 1981). In this study, we defined the level of significance $(\alpha)$ for the confidence ellipse at 0.01 . If the confidence ellipse contained the origin, there was no significant evidence for the drift in the population and the hypothesis that moths showed an overall directed movement was rejected.

\section{Results}

Over all directions, marked moths were recaptured over a range from the release location of 33-9 $528 \mathrm{~m}$ with an average of $1404 \mathrm{~m}$. Seventeen replicates comprising six releases at three locations (except for one date where releases were done at two locations) with a total of 16355 insects released and 1481 insects recaptured were included in the comparison between wind pattern for the day of release and the recaptures summarized on a weekly basis. The net distances for the recaptures ranged from 7 to $9523 \mathrm{~m}$ downwind (median $=790 \mathrm{~m} ; \mathrm{n}=894$ ) (Figure 2) and 3-3 $720 \mathrm{~m}$ upwind (median $=266 \mathrm{~m}$; $\mathrm{n}=587)$. The net distances for the classified recaptures ranged from 6 to $4023 \mathrm{~m}$ crosswind to the left (median $=404 \mathrm{~m} ; \mathrm{n}=681)$ and $1-5697 \mathrm{~m}$ crosswind to the right $($ median $=494 \mathrm{~m} ; \mathrm{n}=800)$. The frequency distributions are significantly different for upwind vs. downwind (Figure $2 \mathrm{~A} ; \chi^{2}=137.789$, d.f. $=4, \mathrm{P}<0.00001$ ) and also for left vs. right (Figure $2 \mathrm{~B} ; \chi^{2}=16.939$, d.f. $=4$, $\mathrm{P}=0.002$ ). The significant difference for left vs. right results from the contribution of the first class $0-250 \mathrm{~m}$ to the overall $\chi^{2}$, because for net distances $>250 \mathrm{~m}$, the frequencies are not significantly different $\left(\chi^{2}=6.841\right.$, d.f. $=3, \mathrm{P}=0.077)$. Conversely, the up- and downwind components differ only for net displacement $>250 \mathrm{~m}$ (Figure 2A) where more recaptures in traps located downwind to the release location were observed.

After normalization of recapture patterns by wind direction, where each recapture is expressed by its angular deviation to the wind, the distributions of recaptures are represented in Figure 3 for each release location. In each case, the furthest distances are observed on the positive ordinate axis which corresponds to the downwind direction. For the three release locations and the pooled data (Figures 3 and 4), Hotelling's test was significant $\left(\mathrm{T}^{2}>\right.$ $\mathrm{T}^{2}$ table $_{(2, \mathrm{n}-2, \alpha)}$ for $\alpha=0.01$ with $\mathrm{n}=325,801,355$, and 1481 for Hobsonville, Waikumete cemetery, Ranui, and all the release locations, respectively), indicating that the sample centre of mass deviated significantly from the origin and pointing towards a displacement in the prevailing wind direction. The centre of mass of all 1481 recaptures was located around $250 \mathrm{~m}$ downwind from the release sites (Figure 4D).

\section{Discussion}

As the recapture dataset used in this study had insufficient temporal precision with respect to trap captures compared to the meteorological information, we were constrained to a comparison of the recapture pattern with declining survivorship over the next 4 days (Suckling et al., 2005a) with the wind on the day of release. Whilst the wind on subsequent days may have influenced the behaviour of moths; the wind on the day of release should have the greatest influence. Clearly, only a small proportion of insects would 

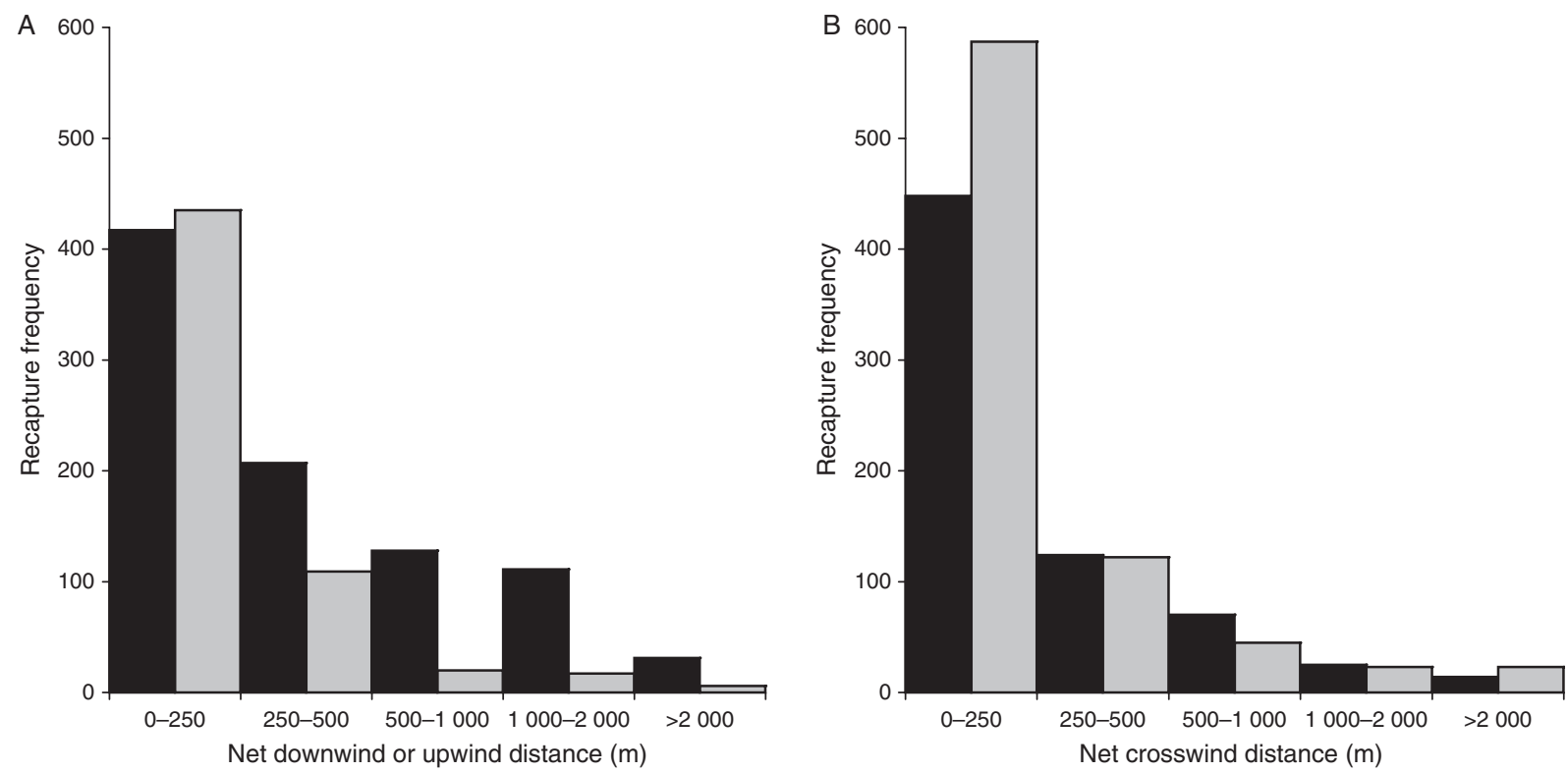

Figure 2 Segregation of recaptures by direction. Frequency distribution of the recaptures classified by the shortest distance between the recapture location and a line orthogonal to the mean wind at the release location for the day of release (A) downwind ( $\square$ ) and upwind ( $\square$ ), frequencies are significantly different using $\chi^{2}$-test; and (B) to the right $(\mathbf{\square})$ or left $(\square)$ relative to the mean wind direction, frequencies are not significantly different for net distances $>250 \mathrm{~m}$ (see text for details).

have survived over the week and we reasonably assumed that the wind direction during the day of release was the main driver for moth dispersal. The spatial recapture pattern over the week following the release had a significant downwind component in relation to first-day average wind direction. This suggests that either the moths have been passively blown downwind or an active behaviour has occurred on the day of release, such as an appetitive flight where insects needed to fly prior to encountering the pheromone. Appetitive downwind flight behaviour has been demonstrated in other species, such as bark beetles (Salom \& McLean, 1989; Franklin \& Grégoire, 1999).

The relationship between wind direction and recapture pattern has been investigated in light brown apple moth, Epiphyas postvittana (Walker) (Suckling et al., 1994), but in the previous study, the authors did not account for the recapture distance which would bias the mean dispersal angle if recapture distances are not uniformly distributed in all directions. In this study, we used Hotelling's test of significance to give an unbiased comparison. For the pooled data, the centre of mass of recapture locations is significantly distinct from the release location and deviated towards the downwind direction. The centre of mass of the pooled datasets (Figure 4D) is located only $250 \mathrm{~m}$ downwind of the release location when data were normalized by the wind direction, whereas some recaptures occurred several kilometres away from the release location.
This result is attributed to the fact that most of the recaptures were observed in traps close to the release location with several recaptures per trap, and less frequent recaptures over a long distance. Furthermore, the combination of downwind dispersal and anemotaxis behaviour to track a female by scent reduces the net downwind displacement contained in the recapture pattern due to the mainly upwind and crosswind movements inherent to the anemotaxis behaviour. It would be interesting to record the behaviour of individual insects from the release site to the trap over a scale of hundreds of metres to some kilometres. In this study, we cannot explicitly segregate appetitive behaviour from passive downwind dispersal, but we demonstrate a downwind displacement in the recapture pattern. The active or passive downwind dispersal supports the findings of Reynolds et al. (2007) who used a harmonic radar study to record an initial downwind movement of A. segetum moths of a few hundreds of metres prior to anemotaxis behaviour.

The recapture distributions (Figure 3 ) include a crosswind component that is important even for recaptures far from the release location. This could be attributed to moths heading at an angle different from the strict downwind direction, when dispersing downwind or the effect of anemotaxis behaviour following the downwind dispersal. However, the wind often shifts in strength and direction as it crosses this maritime-influenced landscape characterised 
A
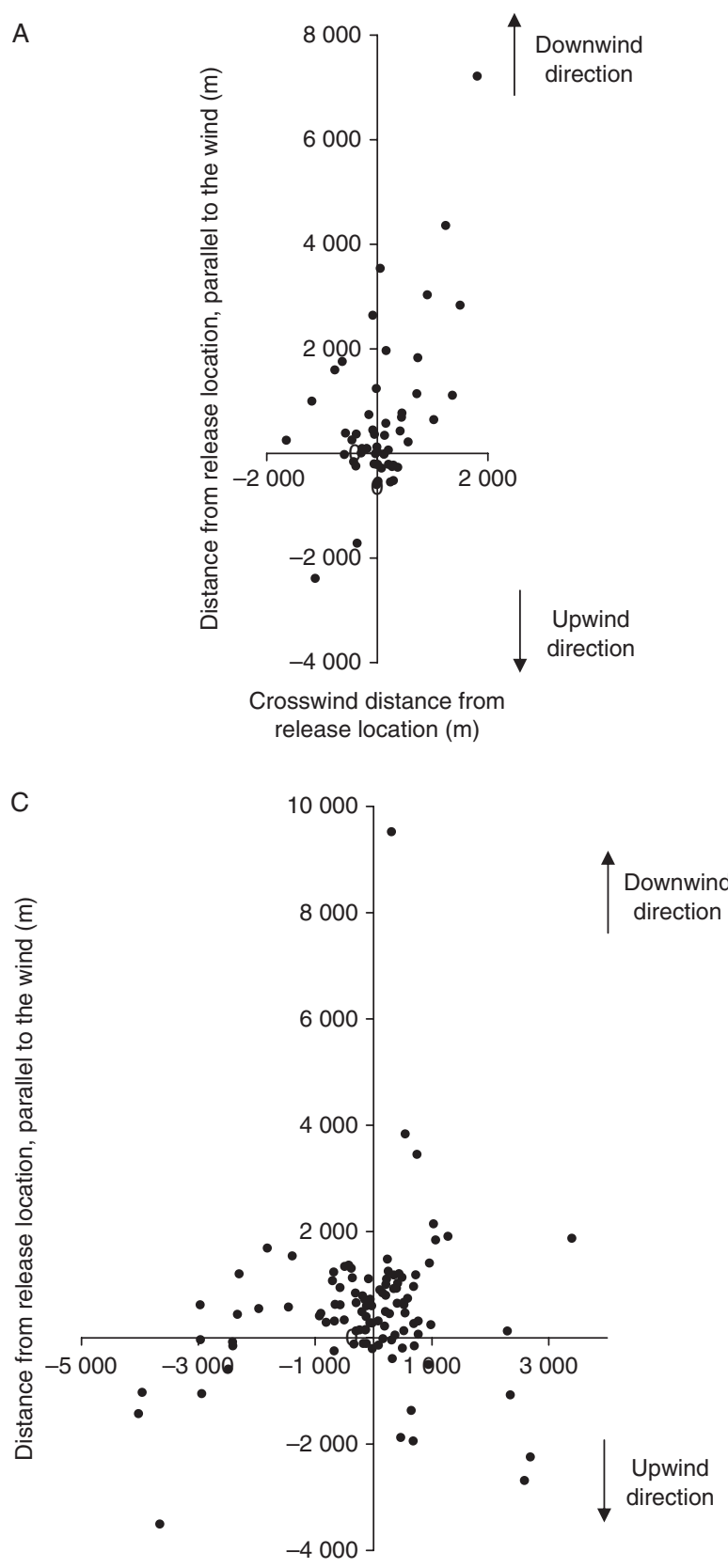

Crosswind distance from release location $(\mathrm{m})$

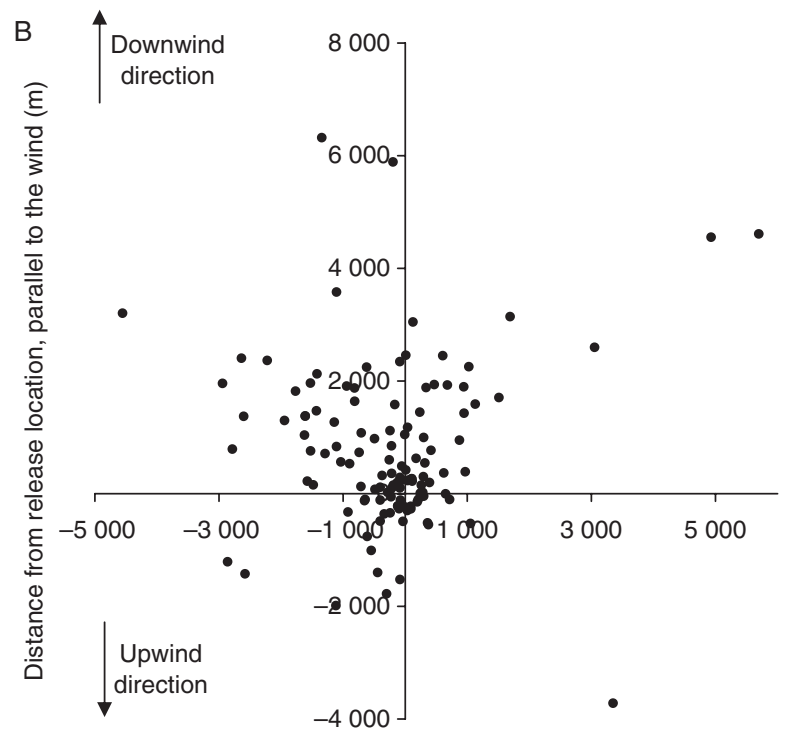

Crosswind distance from release location $(\mathrm{m})$

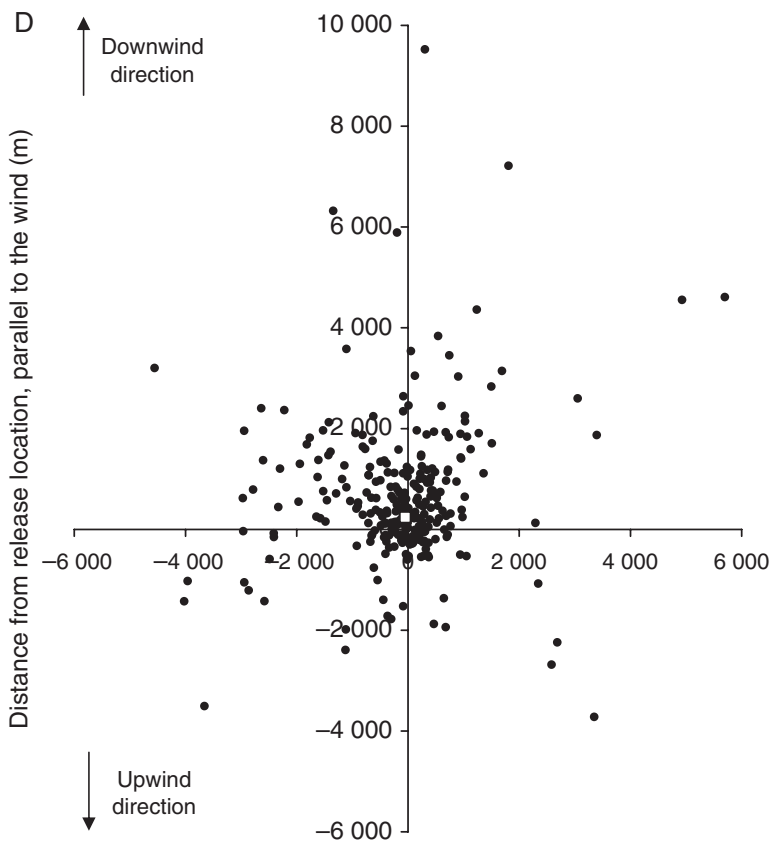

Crosswind distance from release location $(\mathrm{m})$

Figure 3 Recapture pattern $(\bullet)$ after normalization of the recapture direction by the mean wind for the three release locations: (A) Hobsonville, (B) Waikumete Cemetery, (C) Ranui, and (D) for the whole dataset. The downwind direction is represented by the positive ordinate axis.

by topography comprised of extinct volcanoes, and this is also likely to explain some of the crosswind component. For simplicity, and because of limited resources, we used only the wind characteristics at the release location rather than attempting to track the individual moths as they passed across the landscape.
Our study suggests the presence of an important downwind dispersal component in T. anartoides behaviour that would need to be incorporated into any model of its movement. Yamanaka et al. (2003) and Bisignanesi \& Borgas (2007) developed agent-based models to simulate moth behaviour in an environment with pheromone 
Figure 4 Centre of mass $(\square)$ and confidence ellipse $(-$ ) of recapture patterns after normalization of the recapture direction by the mean wind for the three release locations: (A) Hobsonville, (B) Waikumete Cemetery, (C) Ranui, and (D) for the whole dataset. The downwind direction is represented by the positive ordinate axis.
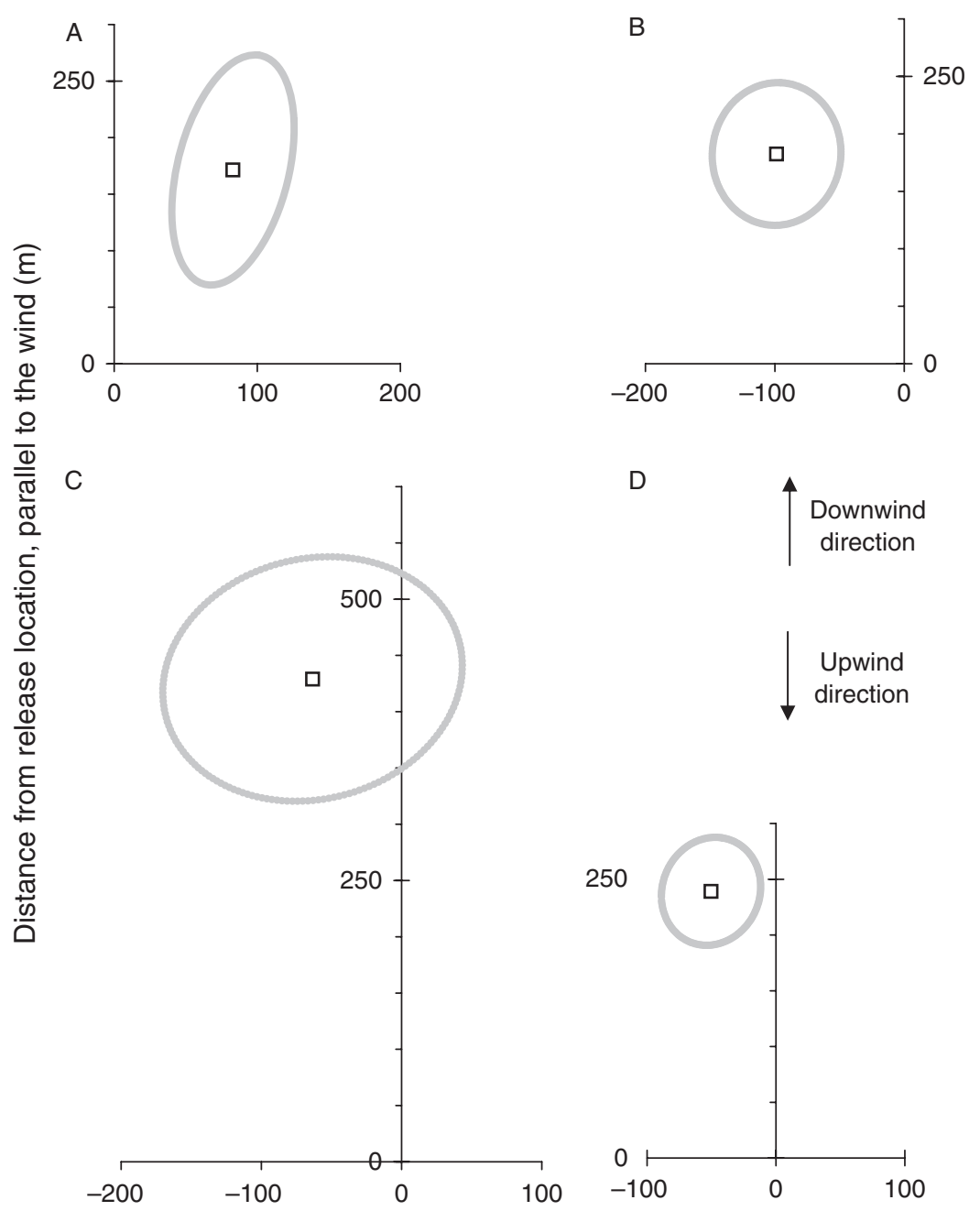

250

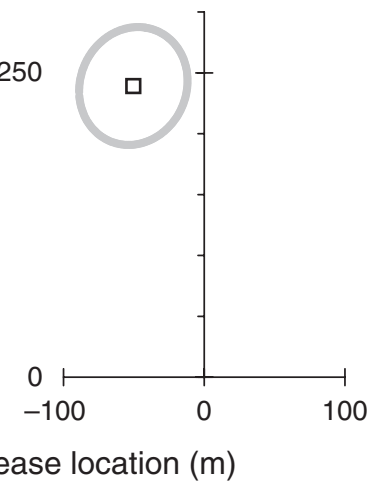

traps, but only included random or crosswind behaviour prior to pheromone detection. Given the potential for relatively high ground speed in comparison to other flight directions, even short-duration downwind flights may result in significant displacement and therefore have a significant impact on the final dispersal patterns of invasive organisms. This behaviour, either passive or active, is likely to be a critical component of any moth dispersal model aimed at identifying the proximal source of an incursion and subsequently to delimit the population. Previous work has suggested that the origin of an insect captured in a pheromone trap is likely to be located downwind, as would be suggested by standard anemotaxis theory alone (David et al., 1983; Cardé, 1984; Ostrand et al., 2000). Noting the downwind trapping results observed in this study, upon detecting an unwanted organism in a trap, delimitation surveys should include areas upwind of the capture site and around the capture site where the majority of recaptures were observed. In biosecurity incursion responses, minimizing ground search efforts to find the source of a pest incursion is critical both in terms of control efficiency and cost reduction (Myers et al., 1998, 2000; Bogich et al., 2008). Future work will focus on developing a modelling framework to improve incursion responses by better targeted searching for potential source populations.

\section{Acknowledgements}

We would like to thank A. M. Barrington and F. Bianchi for their helpful comments. We would like to acknowledge also the Ministry of Agriculture and Forestry Biosecurity New Zealand (MAFBNZ) and the New Zealand's 
National Climate Database for providing meteorological data and R. W. Turner from the National Institute of Water \& Atmospheric Research (NIWA) for the interpretation and use of climatic data in CALMET. This work was funded by New Zealand's Foundation for Research, Science \& Technology through contract C02X0501, the Better Border Biosecurity (B3) programme (http://www.b3nz.org).

\section{References}

Anderton J (2006) Two Auckland Pest Moth Populations Declared Eradicated. Ministry of Agriculture Press Release. http://www.maf.govt.nz/mafnet/press/200306pam.htm.

Augustin S, Guichard S, Svatos A \& Gilbert M (2004) Monitoring the regional spread of the invasive leafminer Cameraria ohridella (Lepidoptera: Gracillariidae) by damage assessment and pheromone trapping. Environmental Entomology 33: 15841592.

Baker TC \& Haynes KF (1987) Manoeuvres used by flying male oriental fruit moths to relocate a sex pheromone plume in an experimentally shifted wind-field. Physiological Entomology 12: 263-279.

Baker TC \& Haynes KF (1989) Field and laboratory electroantennographic measurements of pheromone plume structure correlated with oriental fruit moth behaviour. Physiological Entomology 14: 1-12.

Batschelet E (1981) Circular Statistics in Biology. Academic Press, London, UK.

Bisignanesi V \& Borgas MS (2007) Models for integrated pest management with chemicals in atmospheric surface layers. Ecological Modelling 201:2-10.

Bogich TL, Liebhold AM \& Shea K (2008) To sample or eradicate? A cost minimization model for monitoring and managing an invasive species. Journal of Applied Ecology 45: 11341142.

Canadian Food Inspection Agency (2007) Comparative Report of Engagement Strategies for Invasive Alien Species Among 'QUAD' Countries: Case Studies of Forest Pest Insects. Canadian Food Inspection Agency, Canada.

Cardé RT (1984) Chemo-orientation in flying insects. Chemical Ecology of Insects (ed. by WJ Bell \& RT Cardé), pp. 111-124. Chapman and Hall, London, UK.

Cardé RT \& Willis MA (2008) Navigational strategies used by insects to find distant, wind-borne sources of odor. Journal of Chemical Ecology 34: 854-866.

Common IFB (1990) Moths of Australia. Melbourne University Press, Carlton, Australia.

David CT, Kennedy JS \& Ludlow AR (1983) Finding of a sex pheromone source by gypsy moths released in the field. Nature 303: 804-806.

Dusenbery DB (1989) Optimal search direction for an animal flying or swimming in a wind or current. Journal of Chemical Ecology 15: 2511-2519.
Dusenbery DB (1990) Upwind searching for an odor plume is sometimes optimal. Journal of Chemical Ecology 16: 19711976.

Elkinton JS \& Cardé RT (1983) Appetitive flight behavior of male gypsy moths (Lepidoptera: Lymantridae). Environmental Entomology 12: 1702-1707.

El-Sayed AM, Gibb AR, Suckling DM, Bunn B, Fielder S et al. (2005) Identification of sex pheromone components of the painted apple moth: a tussock moth with a thermally labile pheromone component. Journal of Chemical Ecology 31: 621646.

Fadamiro HY, Wyatt TD \& Birch MC (1998) Flying beetles respond as moths predict: optomotor anemotaxis to pheromone plumes at different heights. Journal of Insect Behavior 11: 549-557.

Franklin AJ \& Grégoire JC (1999) Flight behaviour of Ips typographus L. (Col., Scolytidae) in an environment without pheromones. Annals of Forest Science 56: 591-598.

Hoare RJB (2001) Adventive species of Lepidoptera recorded for the first time in New Zealand since 1988. New Zealand Entomologist 24: 23-47.

Kean JM \& Suckling DM (2005) Estimating the probability of eradication of painted apple moth from Auckland. New Zealand Plant Protection, Vol. 58 (ed. by SM Zydenbos), pp. 7-11. The New Zealand Plant Protection Society, Wellington, New Zealand.

Kean JM, Stephens AEA, Wee SL \& Suckling DM (2007) Optimizing strategies for eradication of discrete-generation lepidopteran pests using inherited sterility. Area-Wide Control of Insect Pests: From Research to Field Implementation (ed. by MJB Vreysen, AS Robinson \& J Hendrichs), pp. 211-220. Springer, Dordrecht, The Netherlands.

Kennedy JS (1983) Zigzagging and casting as a programmed response to wind-borne odour: a review. Physiological Entomology 8: 109-120.

Kennedy JS \& Marsh D (1974) Pheromone-regulated anemotaxis in flying moths. Science 184: 999-1001.

Kennedy JS, Ludlow AR \& Sanders CJ (1980) Guidance system used in moth sex attraction. Nature 288: 475-477.

Kriticos DJ, Potter KJB, Alexander NS, Gibb AR \& Suckling DM (2007) Using a pheromone lure survey to establish the native and potential distribution of an invasive Lepidopteran, Uraba lugens. Journal of Applied Ecology 44: 853-863.

Kuenen LPS \& Cardé RT (1994) Strategies for recontacting a lost pheromone plume: casting and upwind flight in the male gypsy moth. Physiological Entomology 19: 15-29.

Kuenen LPS \& Rowe HC (2006) Cowpea weevil flights to a point source of female sex pheromone: analyses of flight tracks at three wind speeds. Physiological Entomology 31: 103-109.

Liebhold AM \& Tobin PC (2008) Population ecology of insect invasions and their management. Annual Review of Entomology 53: 387-408.

Mafra-Neto A \& Cardé RT (1994) Fine-scale structure of pheromone plumes modulates upwind orientation of flying moths. Nature 369: 142-144. 
Mafra-Neto A \& Cardé RT (1998) Rate of realized interception of pheromone pulses in different wind speeds modulates almond moth orientation. Journal of Comparative Physiology A 182: 563-572.

Murlis J \& Jones CD (1981) Fine-scale structure of odour plumes in relation to insect orientation to distant pheromone and other attractant sources. Physiological Entomology 6: 71-86.

Murlis J, Elkinton JS \& Cardé RT (1992) Odor plumes and how insects use them. Annual Review of Entomology 37: 505-532.

Myers JH, Savoie A \& van Randen E (1998) Eradication and pest management. Annual Review of Entomology 43: 471-491.

Myers JH, Simberloff D, Kuris AM \& Carey JR (2000) Eradication revisited: dealing with exotic species. Trends in Ecology and Evolution 15: 316-320.

Ostrand F, Anderbrant O \& Jonsson P (2000) Behaviour of male pine sawflies, Neodiprion sertifer, released downwind from pheromone sources. Entomologia Experimentalis et Applicata 95: 119-128.

Reynolds AM, Reynolds DR, Smith AD, Svensson GP \& Löfstedt C (2007) Appetitive flight patterns of male Agrotis segetum moths over landscape scales. Journal of Theoretical Biology 245: 141-149.

Riffell JA, Abrell L \& Hildebrand JG (2008) Physical processes and real-time chemical measurement of the insect olfactory environment. Journal of Chemical Ecology 34: 837-853.

Riley JR, Valeur P, Smith AD, Reynolds DR, Poppy GM \& Löfstedt C (1998) Harmonic radar as a means of tracking the pheromone-finding and pheromone-following flight of male moths. Journal of Insect Behavior 11: 287-296.

Sabelis MW \& Schippers P (1984) Variable wind directions and anemotactic strategies of searching for an odour plume. Oecologia 63: 225-228.

Salom SM \& McLean JA (1989) Influence of wind on the spring flight of Trypodendron lineatum (Olivier) (Coleoptera, Scolytidae) in a second-growth coniferous forest. Canadian Entomologist 121: 109-119.

Scire JS, Robe FR, Fernau ME \& Yamartino RJ (1998) A User's Guide for the CALMET Meteorogical Model (Version 5). Earth Tech, Concord, MA, USA.

Self M (2003) Biosecurity: the implications for international forestry trade. The Australian and New Zealand Institutes of Forestry Conference (ed. by EG Mason \& CJ Perley), pp. 59-63, Queenstown, New Zealand.

Suckling DM, Brunner JF, Burnip GM \& Walker JTS (1994) Dispersal of Epiphyas postvittana (Walker) and Planotortrix octo
Dugdale (Lepidoptera, Tortricidae) at a Canterbury, New Zealand orchard. New Zealand Journal of Crop and Horticultural Science 22: 225-234.

Suckling DM, Charles J, Allan D, Chaggan A, Barrington A et al. (2005a) Performance of irradiated Teia anartoides (Lepidoptera: Lymantriidae) in urban Auckland, New Zealand. Journal of Economic Entomology 98: 1531-1538.

Suckling DM, Gibb AR, Dentener PR, Seldon DS, Clare GK et al. (2005b) Uraba lugens (Lepidoptera: Nolidae) in New Zealand: pheromone trapping for delimitation and phenology. Journal of Economic Entomology 98: 1187-1192.

Suckling DM, Hackett JK, Chhagan A, Barrington A \& El-Sayed AM (2006) Effect of irradiation on female painted apple moth Teia anartoides (Lepidoptera: Lymantriidae) sterility and attractiveness to males. Journal of Applied Entomology 130: $167-170$.

Suckling DM, Barrington AM, Chhagan A, Stephens AEA, Burnip GM et al. (2007) Eradication of the Australian painted apple moth Teia anartoides in New Zealand: trapping, inherited sterility, and male competitiveness. Area-Wide Control of Insect Pests: From Research to Field Implementation (ed. by MJB Vreysen, AS Robinson \& J Hendrichs), pp. 603-615. Springer, Dordrecht, The Netherlands.

Turner JA, Bulman LS, Richardson B \& Moore JR (2004) Costbenefit analysis of biosecurity and forest health research. New Zealand Journal of Forestry Science 34: 324-343.

Vickers NJ (2000) Mechanisms of animal navigation in odor plumes. Biological Bulletin 198: 203-212.

Vickers NJ \& Baker TC (1996) Latencies of behavioral response to interception of filaments of sex pheromone and clean air influence flight track shape in Heliothis virescens (F.) males. Journal of Comparative Physiology A 178: 831-847.

Wang W, Shaw WJ, Seiple TE, Rishel JP \& Xie Y (2008) An evaluation of a diagnostic wind model (CALMET). Journal of Applied Meteorology and Climatology 47: 1739-1756.

Williams IH, Frearson D, Barari H \& McCartney A (2007) Migration to and dispersal from oilseed rape by the pollen beetle, Meligethes aeneus, in relation to wind direction. Agricultural and Forest Entomology 9: 279-286.

Yamanaka T, Tatsuki S \& Shimada M (2003) An individual-based model for sex-pheromone-oriented flight patterns of male moths in a local area. Ecological Modelling 161: 35-51.

Zanen PO \& Cardé RT (1999) Directional control by male gypsy moths of upwind flight along a pheromone plume in three wind speeds. Journal of Comparative Physiology A 184: 21-35. 